\title{
THE PROBLEMS OF CITY GOVERNMENT FROM THE ADMINISTRATIVE POINT OF VIEW
}

\author{
By John A. Fairlie, \\ University of Michigan, Ann Arbor.
}

Much has been written during recent years about the defects of American municipal government. And all sorts of remedies have been proposed, and many of them put to the test of experience. Discussion and agitation, followed by legislation and the election of better officials, have wrought great improvement in many communities; and even the most recent disclosures of intolerable conditions have been signs of an awakened public opinion and the direct cause of uprooting some evils. But no one has suggested that we have as yet reached a state of perfection in municipal government, or that we are in any immediate danger of attaining such a state.

It is not the purpose of this paper to discuss all of the problems that have arisen in connection with our municipal affairs, nor to propose remedies for all of the difficulties and evils that still exist. No attention will be given to such questions as the scope of municipal functions or the political substructure underlying the organization of government. The task here undertaken is to consider only those features of the complex municipal situation on which a student of public administration may be supposed to be able to throw some light.

These features may be considered under two main heads: (I) the problems connected with the local machinery of municipal organization and the inter-relations of local officials; and (2) the problems connected with the relations of the city to the government of the state. Under each division, the existing arrangements will be briefly summarized, their defects will be pointed out and the various remedies hitherto applied, and plans will be suggested for future action. It will be admitted frankly that no scheme of purely ad- 
ministrative reform will offer a complete solution of all the municipal problems; but it is a false logic which deduces from this the belief that administrative reform is of no importance; and this paper is written in the conviction that some of the fundamental difficulties are administrative in character, and that administrative reforms are among the essential conditions of successful municipal government in this country. The basis for the discussion of administrative reforms will be found in a municipal program, adopted by the National Municipal League; but amendments to this plan as seem desirable will also be suggested.

\section{Local Organization.}

One of the first facts that becomes obvious to any student of municipal government in the United States is the confused and complicated variety of local administrative arrangements, and the lack of consistent principles of municipal organization, not only in the cities as a whole, but even in most of the cities taken individually. Starting with a simple system of council government, this was first altered about $I 820$ by a limited application of the theory of the separation of legislative and executive powers in the popular election of mayors; while subsequently ( in the hands of separate and largely independent authorities has been developed to a remarkable degree, without any guiding principle and in a way that defies generalization or classification. In more recent years, some of our cities have secured a system of municipal organization based in part at least on some fundamental ideas. These have been for the most part a stricter application of the theory of separation of the legislative and executive powers, with the concentration of the latter in the hands of the chief executive, as in the national administration; but in a few cases the centralization of authority in the hands of the mayor has tended towards the abandonment of the theory of separation.

There are two factors in American municipal organization which are practically universal, and may therefore be taken as the necessary bases for any systematic scheme. These are a council and a mayor, both elected directly by popular vote. Washington, D. C., is the only city which has been an exception to this rule for any considerable length of time; and the administrative arrangements 
there could not be well applied elsewhere, even if they formed in themselves a correlated and consistent scheme of organization.

\section{The Council.}

When we turn to examine the structure and powers of these two common factors, we find ourselves at once in the midst of diversity and often of confusion. The typical form of the council is that of a single body elected by wards or districts for a one or two year term. Many of the large cities-six out of the twelve with over 300,000 population-have a bicameral council. In many of these the smaller branch of the council is elected from the whole city instead of by districts; the cities in Ohio, Indiana and Iowa and some others have a small number of councilmen elected at large, in addition to the ward representatives; and in San Francisco and a few other cities the whole membership of the council is chosen at large. In most American cities council members now receive some compensation; but the older rule of gratuitous service still prevails in New England, Pennsylvania, and is frequently found in Southern cities and occasionally in other parts of the country.

Almost every one of these elements of council organization has been the subject of criticism. It is pointed out that a single council elected by wards, even if successful in representing the local interests of the various districts, makes no adequate provision for the general interest of the whole city. In addition the district system offers other difficulties in cities, and especially in large cities. The ward limits are artificial and seldom represent any natural social grouping of the population. Frequent changes of boundaries and the constant changes of residence on the part of the people hinder the development of a common social life within the political district. While even in the face of readjustments of boundaries, population movements go on so rapidly that there is seldom even the crudest approximation to representation in proportion to population; and in the largest cities at least the districts over-represented are those in the control of the worst elements in the population.

A bicameral council with one house elected at large might seem to meet some of these objections; but in fact, as generally established, it simply adds another body chosen in a way which prevents the representation of different interests, and thus weakens the de- 
liberative character of the council. In practical experience, too, it has not been found that the bicameral system is in any way necessary, or that it secures any improvement in the management of municipal affairs.

In reference to salaries, it is urged on the one hand that no payment induces aldermen to accept or to demand compensation for their services in an irregular way, which often becomes either a system of bribery or blackmail; and on the other hand it is said that any salary makes the post one for which impecunious politicians will enter into active competition.

The plan of the National Municipal League recommends the election of a single chambered city council on a general ticket, although providing for the possible retention of the district system in cities of over 25,000 . Does not this go too far in ignoring the idea of local representation? It may be admitted that the present ward system is usually unsatisfactory; but are there not in every city sectional divisions with tolerably distinct municipal interests and some elements of common social life? Such divisions ought to be recognized and emphasized in the political system. They should have fairly permanent boundaries; and the district for electing council members should be also a district for other municipal purposes, such as schools, police, fire brigade and the like, and indeed still further for larger political interests, such as the election of members of the state legislature. By thus concentrating the political interests of the same people in a common district, the germ of social unity and local spirit could be highly developed. Such districts would ordinarily be larger than city wards at the present time, and the internal transfers of population within the city would be more largely within the district, and would thus more often be made without requiring any readjustment of political relations. Moreover, as each district would have several members in the council, the exact number could be adjusted at frequent intervals in proportion to the changes in population, without changing district boundaries.

Besides such a district system, the plan now in use in several states of the Middle West, of electing a small number of members of the council at large also seems desirable. Such members would probably be more widely known throughout the city, and likely on this account to be men of large ability and character, and also likely to secure better consideration for the questions where local interests 
should give way to more general views. It may further be noted that these arrangements are adapted to various forms of minority and proportional representation; but even without this feature the district members will undoubtedly include representatives of different shades of political opinion on various questions of public policy, and the council will thus continue to be a body adapted to deliberation and discussion.

A system of council organization somewhat similar to that outlined was in operation in New York City from 1873 to 1882 . And it is perhaps worthy of note that during this decade there was less criticism of municipal government in the metropolis than in any other period of equal length for the last fifty years, and that the abandonment of the system was due, not to any public dissatisfaction, but apparently for the sole purpose of strengthening the system of party machinery and increasing partisan influences in the municipal government.

An examination of the powers of municipal councils involves two distinct-or at least distinguishable-topics: the subject matter of council activity, and the methods of council action. In both fields the diversity of detail and the difficulty of generalization is enormous. It may, however, be said, under the first head, that municipal councils generally have some power in reference to the protection of persons and property and the construction and management of local works of public improvement, and often they have some control over public charity; but seldom do they have much direct voice in reference to public education. In any case the authority of the council is strictly limited to the specific grants made by the state legislature. These legislative grants are not given in general terms, but are minutely enumerated, and the courts have uniformly applied the doctrine of strict construction to all such grants. In consequence, while in the smaller cities the councils have ordinarily about as much authority as they wish to exercise, in the larger cities where the need and demand for municipal action is much greater, the councils are constantly appealing to the legislature for larger powers.

Methods of council action may be considered as legislative or administrative. In their constitution, municipal councils are organized on similar principles to our legislatures; and this idea has been retained in the plan proposed in this paper. And in a vague sense the councils have been considered as the body in the municipal gov- 
ernment corresponding to the legislatures in the state and national governments. But it must be said that the law-makers have never thoroughly recognized this. Indeed, the judicial doctrine laid down as a general rule, that all legislative power not granted to Congress is vested in the state legislatures and may not be delegated, is in direct contradiction to the idea that the councils are legislative bodies. Nevertheless, some state constitutions have expressly provided that local legislative power may be delegated to local bodies; while the body of statutory legislation on municipal government does in fact give a certain amount of legislative power to municipal councils.

Legislative power as exercised by Congress and the state legislatures seems to consist of three main elements : the power to enact laws applying to the community at large; the power to organize a system of officials and regulate their functions, and the power to levy taxes and appropriate money to maintain the administrative system thus organized. Municipal councils have the first of these to a limited degree, in their power to enact local ordinances and bylaws on specified subjects. But such ordinance power is sometimes given to administrative authorities such as boards of health, police commissioners and park boards. They have the third class of powers also to a more or less limited extent. But they have in most cases only a most restricted authority in reference to powers of the second class.

As to the power over administrative organization, municipal charters usually provide so completely for all the officials of any importance, that the municipal councils find little scope for further action except in the creation of minor positions such as milk inspectors or sealers of weights and measures; and in many of the larger cities this power of establishing minor offices is vested not in the council, but in an authority supposed to be administrative,-while in the new Ohio code such power has been given to the boards of public service in every city in that state. In this respect city charters have carried to an absurd extreme a feature of our state constitutions, where these have departed from the altogether excellent model laid down in the national constitution.

One state stands out as a notable exception to this rule. The municipal corporation act of Illinois, after providing for a comparatively small number of officials in every city, authorizes the municipal council by a two-thirds vote to establish such other offices 
as it deems necessary, and to discontinue any of these offices by a like vote at the end of a fiscal year. Thus in the city of Chicago such important offices as that of comptroller and commissioner of public works have been established by council ordinance.

In the exercise of such legislative powers as they have, municipal councils are generally restricted by the veto power of the mayor, in the same way as Congress and most of the state legislatures are restricted by the veto power of the President and governors.

In most of the smaller cities, and in New England and Pennsylvania even in cities of considerable size, municipal councils still retain and exercise many administrative powers. To some extent these powers are exercised by the council as a whole, by the issuance of specific orders to agents and employees, and by the appointment of officials and their subordinates. In other respects, such powers are exercised immediately by council committees, who have direct supervision over the municipal employees. Even in the larger cities where these powers are no longer in the hands of the councils, appointments to office are effective only after being confirmed by them, this control over appointments being sometimes used to secure some patronage for the individual members. In Chicago and many of the large cities, as well as the smaller ones, the council through its Finance Committee is the controlling factor in initiating proposals for expenditure as well as in passing the appropriations; but in the larger cities of New York state and some other cities the budget is prepared by a small administrative board, and the council is not permitted to appropriate more than the sums provided in the budget.

Under the program of the National Municipal League, the scope of municipal action would be vastly increased. The ordinance power is to include general authority in reference to the "good government, order and security of the city and its inhabitants." Broad grants of power to deal with public works, institutions and certain commercial undertakings are given; and these are made effective by a comprehensive grant of taxing power. The council is made the general legislative authority in all matters, subject, however, to the veto power of the mayor; and with detailed restrictions in reference to granting away rights and franchises in the public streets. The council, too, is to have almost complete power in organizing the administrative departments. On the other hand, the council cannot appoint to any office, except that of comptroller; and it seems to 
be intended that the council shall have no powers of direct administration.

Several recent municipal charters have provisions along the line of those recommendations. The general law for the four cities of the second class in New York state vests the legislative power and only the legislative power in the city councils. A more emphatic statement is placed in the new. charter of Portland, Ore.; and another in the latest (1900) charter of the city of New York. But it would seem that these clauses refer only to the ordinance power; and the equally important power of organizing administrative offices has apparently been effectively granted only in the law of Illinois previously mentioned. ${ }^{1}$

It is not entirely clear that all municipal councils should be restrained from exercising any administrative functions. In small cities where the amount of municipal work is limited, there is no absolute necessity for separating legislative and administrative functions, and council committees may well discharge the latter duties and save the expense of additional officials. In large cities, the distinction is much more important; the increased volume of business makes too great a demand on the time of aldermen than can safely be demanded from the kind of men who ought to be members of the councils; and better administrative management can be secured by specializing that work in the hands of experts in the different fields who can be paid to give their whole time to the municipal service.

"With a careful separation of powers the legislative function can be entrusted to typical everyday Americans from middle life who yet have broad enough training to enable them to see the interests of the city as a whole. In most cities strictly legislative duties would not seriously interfere with a man's regular business, and therefore the councilmen need not either be rich or receive high salaries from the city."2

The Mayor.

The mayor has the longest pedigree of any of our American public officers. As far back as the sixth century we hear of the

1 In Michigan where the state constitution specifically authorizes the legislat ure to confer local legislative power on city councils, the Supreme Court has held that this applies only to the power of passing general ordinances, and that the legislature may not delegate to city councils the power of organizing administrative departments.

2 Wilcox: The American City, p. 306. 
mayors of the palace in the Frankish kingdoms, the last of whom, Karl Martel, was grandfather to the Emperor Charlemagne. A few centuries later the name appears again both in France and England as the chief officer of a city, and in that capacity it has come down to our own time. American mayors occupy an intermediate position between the purely honorary and social dignity of the English office and the professional public administrator of Germany, with a tendency in recent years to confer on the officer legal powers in some respects analogous to those of a mayor in France. In this country the office is filled by direct popular vote, for terms varying from one to four years. The one year term is too short; it should be at least two. In most cities of over 25,000 population, and in many smaller cities, the incumbent receives a salary,-in cities with over 100,000 population, usually from $\$ 2,000$ to $\$ 5,000$ a year, and in five cities from $\$ 10,000$ to $\$ 15,000 .^{3}$

Although generally considered as primarily an executive officer, the mayor has always had important duties in relation to the council and legislative matters. In small cities, he is in most cases the presiding officer of the council; and has this position even in such important cities as Chicago, Providence and Grand Rapids. In the last named he also appoints the committees of the council. But in most of the larger cities this connection of the mayor with the council has ceased. On the other hand, in all the larger cities and many small cities, he has a limited veto over the acts of the council, which in many cases includes the power to disapprove items in appropriation bills, sometimes includes the power to disapprove separate provisions of any ordinance, and in a few cities is made more effective than the veto power of the President and state governors by requiring a larger vote than the traditional two-thirds to override his disapproval. In the cities of New York state; the mayors have an additional legislative power to disapprove special acts of the state legislature applying to their cities, this disapproval operating as a veto unless the legislature repasses the bill.

In respect to administrative powers, the principles of executive authority employed in the national government have been but slowly and partially applied to city mayors. In many small cities, and in some of considerable size (the latter mostly in New England and Ohio) the mayor has even yet little or no appointing power and no

${ }^{3}$ Racine, Wisconsin, seems to be the largest city where no salary is paid. 
effective means of controlling the other officials; and has thus still less relative authority than most of the state governors. In other cities, including most of the larger places, he now generally has powers analogous to those of a state governor: the right to nominate to the council for the principal positions not filled by popular election, and some power of removing officials for cause. In Illinois cities, the scope of this limited power over appointments may be greatly enlarged as the council creates new offices; and in the same state the mayor has also a large power of removal which gives him effective means of control over the other officials and strengthens his influence in appointments. In Chicago the mayor's power of nomination extends to most of the important positions, and in practice has been equivalent to the absolute power of appointment. In Cleveland for twelve years (I89I-I903) the mayor had a very extended power of nomination, which in practice operated to give him complete control over most of the important positions.

During the last ten years, in a number of important cities, the mayor's power of appointment and removal has been still further increased. The mayors of the six largest cities in New York state, of Boston, of all cities in Indiana, and of a few other cities have now the sole and absolute power of appointing the heads of most of the municipal departments; and in the same cities, with the addition of the four largest cities in Pennsylvania, mayors have the power of removing at any time the appointed heads of departments. Under this system the executive authority and responsibility is concentrated in the mayor, except for a few officials still elected by popular vote.

In the program of the National Municipal League, this latest development of the mayor's authority is adopted, and indeed strengthened by making the mayor the only elective executive officer, and extending his power of appointment and removal to all administrative officers except the comptroller. At the same time the mayor's limited veto power over council ordinances is retained; and he is also to prepare and submit the annual budget.

This concentration of executive authority in the hands of the mayor has been criticized, as enabling that official to use his power to build up a "political machine." This was the main argument of those who planned the recent Ohio municipal code, which relegates the mayor to a position of "innocuous desuetude," yet the system there established was that which has enabled one of the most notori- 
ous "machines" in the country to be maintained in the city of Cincinnati. Every system of appointment or election can be abused in this way, so long as positions in the municipal service are given as rewards for campaign work. The complete plan of the National Municipal League will restrict the possibility of this abuse to small limits by the merit system in filling all subordinate positions; and it is felt that the importance of the principal offices and the responsibility of the mayor's power will in most cases secure the appointment of competent heads of departments.

One writer in a very recent article advocates a still further development of executive authority. ${ }^{4}$ He holds that the organic defect in municipal organization "lies in the fact that the executive and legislative departments, in addition to being separately constituted, are also disconnected, and this very disconnection has prevented in practice the degree of separation in their functions which their integrity requires." His remedy is to give the executive complete legislative initiative, with the right to demand a vote on proposed measures.

\section{Administrative Departments.}

Our discussion of the officials who deal with particular branches of municipal administration must be very brief. Any description of existing arrangements is out of the question, for the situation may well be described as chaotic:-a chaos in regard to the forms of organization, the terms of service, the methods of election or appointment, and the relations of the various officials to the council, to the mayor and to each other. A large element of variety in some of these respects is almost inevitable: the number of officials and separate departments must vary with the size of the city and the scope of municipal functions; and the extent to which unsalaried service can be advantageously secured can hardly be fixed by a hard and fast rule. But the existing confusion goes far beyond what is either necessary or excusable; and is the cause of constant friction and dissatisfaction in municipal operations.

Something may be said about conditions in those cities where a more orderly system has been introduced. Most of the cities where the mayor's power has been increased, place single salaried commissioners at the head of the various departments, and

'H. J. Ford, in Annals of American Academy.ofIPolitical and Social Science, March, 1904. 
some other large cities, e. g., Detroit, have also partially introduced this same feature. But in every case some branches of administration remain under the supervision of boards, and there is no fixed rule as to which departments are under boards and which under single commissioners.

In most cities the various municipal bureaus form a heterogeneous list, frequently numbering from twenty to thirty or more, with no official connection even between those whose duties are most closely related. But a number of cities have made progress in grouping related offices into important departments. Thus in St. Louis the heads of the various public works bureaus, including the parks, streets, sewers and water bureaus, are brought together in the board of public improvements; and in the larger cities of New York and Pennsylvania the public works department has been made to include most of the bureaus of this kind. In Ohio cities, under the new code, the department of public service embraces not only the management of all the municipal engineering works, but also the charitable and correctional institutions, going too far in combining unrelated offices. Another development has been in establishing departments of public safety, bringing together the police and fire brigades and usually also the offices for sanitary and building inspection. This department is now to be found in some of the larger cities of New York, Pennsylvania and Indiana, in all the Ohio cities, and occasionally in other places.

Most advance in this direction is to be found in the four cities of the second class in New York state. Here practically all the municipal service is organized in seven main departments. This plan seems to have been taken, with some modifications, from the so-called "federal plan" of Cleveland (I89I-I903); and another feature of that plan is authorized in the New York cities, viz: the periodic meetings of the heads of departments with the mayor, as a cabinet for the discussion of questions of common interest to secure agreement on harmonious lines. In Cleveland the "cabinet" was constituted as a board of control with important legal powers; but in the New York cities it has been left to develop its own place in the municipal system.

In the new municipal code of Indiana (I905) from five to eight departments are established in cities of over I0,000 population, and provision is made for monthly meetings of the mayor and the heads 
of departments. This "cabinet" is authorized to adopt rules and regulations for the administration of the departments, including rules governing admission to the subordinate municipal service.

The plan of the National Municipal League does not provide in detail for the administrative departments; but leaves these to be organized by the council or by the special locally framed charters according to the needs of the city. But there is certainly need in most cities for more careful attention to this problem of departmental organization; and the larger cities of the country will find the plans that have been mentioned well worth their attention.

Subordinate positions in the municipal service in most cities are filled and held at the pleasure of the changing heads of departments and bureaus. And one of the most serious abuses in municipal administration has been the frequent changes in such positions for partisan and political purposes. In the cities of Massachusetts and New York, and in Philadelphia, Chicago and New Orleans the system of open competitive examinations has been established. And in some other cities the police and fire departments are recruited under a merit system. There can be no question that the principles of civil service reform should be thoroughly applied to the whole municipal service.

\section{The City and the State.}

Of equal importance with the problem of local organization are the problems of the relations between the city and the state. For in the United States, as in all other countries, cities are not independent political communites, but districts in a larger political area and subordinate in various ways to the higher governmental authorities. In the United States this subordination is to the government of the states. There are many evidences that the prevailing relations between the city and state authorities are unsatisfactory, and the remedy most widely suggested is a demand, usually vague and inarticulate, for municipal "home rule." Some attention may therefore be given to explaining the present arrangements and to presenting a definite plan for a better system.

At the outset it may be noted that in our fundamental political document, the national constitution, cities are in no way recognized as having any existence; and that under the principle of residual powers, the cities are created by the states, which have complete 
power of control over them, and may even destroy their political existence. ${ }^{\sigma}$ But the powers of the states are for the most part exercised by the state governments; and these are established and limited by the state constitutions. The more practical question is therefore as to the relations of the cities to the state legislatures, the state executive and administrative authorities and the judiciary.

\section{Legislative Control.}

In the absence of specific limitations in the state constitutions, the power of the legislature in most states is held by the courts to be practically co-extensive with the power of the states. A municipal corporation has only such powers as are expressly enumerated or clearly implied in its charter or the general laws; and the legislature "may, where there is no constitutional inhibition, erect, change, divide and even abolish them at pleasure, as it deems the public good to require."B

In Michigan, however, and to a less extent in Indiana this doctrine has been somewhat modified; and the courts have held that the legislature may not vest distinctively local powers, such as management of public works, in state officers, and may not compel a city to undertake local improvements without its consent. More generally, too, it has been held that the constitutional guarantees for the protection of private property, prevent the legislature from confiscating the private property of a city. But with these exceptions, restrictions on the power of the legislature must be based on specific constitutional provisions.

State legislatures, in the exercise of this power over cities, have generally granted the authority to elect local officials; but have regulated in minute details the organization of the municipal government and the powers and functions of the municipal officials. In earlier days, and even at the present time for most small cities, statutes on municipal government have usually been enacted only on local initiative and, generally at the request of local members of the legislature without consideration by the whole legislature or any public notice. As a result, there has accumulated a great mass of special legislation in most of the states, overloading the statutes with heterogeneous and conflicting provisions, which make almost

s U. S. v. B. \& O. R. R. Co., I7 Wall. 322 (1872).

- Dillon Municipal Corporations, I, 93. 
impossible an intelligent understanding of municipal government and dissipate and confuse responsibility for local affairs.

In most of the states containing large cities, legislation for their government has been affected by other considerations. Charters and charter amendments are passed not only without public and local discussion, but also, in many cases, against the wishes of the local officials and local members of the legislature. Sometimes such legislation has had ostensibly at least, the immediate object of remedying some municipal delinquency; but in many cases the most effective motive has been to secure some partisan advantage for those in control of the state government, when the city officers belong to another political organization; while in some instances such legislation has been enacted through the worst sort of political jobbery, to confer privileges which could not be secured from the local authorities. By such means acts have been passed substituting state appointed officials for local officers, compelling cities to carry out expensive and unnecesary undertakings, and granting franchises in the public streets with little or no compensation to the city. The legislatures of New York, Pennsylvania, Ohio and Missouri have been most active in these methods of interference; but instances are not lacking in Massachusetts, Illinois, Michigan and other states.

It is over fifty years since the attempt was begun to remedy the evils of special municipal legislation by constitutional provisions prohibiting such legislation. The second constitution of Ohio, adopted in $185 \mathrm{I}$, contained several clauses intended to abolish special legislation on municipal government; other states followed this example, at first slowly, but more rapidly since 1870 ; and at the present time about half of the states forbid the legislature to enact special municipal legislation. These provisions have, however, had only a partial success. The method of detailed legislation enumerating municipal officers and powers was so firmly established, that when it proved difficult to pass laws of that nature applying to cities of all sizes, the lawmakers, instead of changing their method of legislation, devised methods of evading the constitutional provisions. The most successful method was the device of classifying cities; as the courts accepted a statute applying to a class of cities as a general law, even if there were only a single city in a class. The smaller cities were then grouped into one class, and a general law applied to them; but each of the larger cities was usually placed in a class by itself; and 
the régime of special legislation with its evils of confusion, partisanship and corruption continued, and indeed became worse than ever with the development of cities in size and population.

In Illinois an effective general municipal law was enacted in I872, which by granting large powers to all cities has been success$\mathrm{ftul}$ in limiting special legislation in that state. But even there some special legislation has been enacted, mainly because the financial powers granted in the general law are not adequate to the needs of the city of Chicago. In Ohio, too, after fifty years of classified legislation, the Supreme Court of the state felt compelled in 1902 to reverse its previous rulings and to declare that statutes for a class of cities which in fact applied only to a single city were contrary to the state constitution. The result was the enactment of a new municipal code applying to all the cities of that state, which, however, still goes so much into detail that it burdens the smaller cities with a too cumbersome machinery. The new municipal code of Indiana reduces the number of classes of cities in that state to five. And Virginia has a general municipal law, supplemented, however, by some special legislation. In some other states the smaller cities are organized under a general law.

New York state in 1894 adopted another method, in the attempt to reduce the evils of legislative interference in municipal affairs. The revised constitution of that year itself establishes three classes of cities, and provides that any bill applying to less than all the cities in one of these classes must be submitted to the city concerned, and if disapproved by the mayor or the mayor and council must be repassed by the legislature and signed by the governor before it can become a law. These provisions have secured a greater amount of publicity to special legislation and have prevented the enactment of some bills rushed through the legislature without careful consideration. In the case of bills passed towards the end of the session, the mayor's disapproval is also effective until the next session of the legislature. But in many cases the mayor's disapproval has served only to delay the enactment; and partisan or corrupt influences have secured the passage of measures over the local disapproval.

At the session of the Michigan legislature in 1903 a method of procedure was adopted in reference to bills affecting the city of Detroit, which secured the same advantage of publicity. At the request of the Common Council of Detroit, no Detroit bill was placed 
on its third reading, until after a public hearing on the measure in the city. Such hearings were held regularly on Saturday mornings during the session, being attended by the local members of the legislature, a committee of the council, the newspaper reporters, and any one interested in particular bills. This procedure could be established in every state, and it ought not to be a difficult matter to secure it. During the year it was in operation in Michigan, it prevented the enactment of all measures to which there was strong local opposition. It has proved, however, inadequate as a means of securing needed legislation, owing to the difficulty of harmonizing the different factors.

Another method which prevents some of the abuses of legislative interference is found in the constitutions of New York and Kentucky, which provide that all local officers must be locally elected. Even this, however, has been evaded by creating special districts with appointive officers for the conduct of functions usually municipal, or by transferring such functions and officers from the city to the county.

Still another method found in several of the states west of the Mississippi river, is that of allowing cities to frame their own charters through a local convention analogous to a state constitutional convention. A constitutional provision authorizing this was first adopted in Missouri in 1875 for cities of over 100,000 population, when it was early applied in the city of St. Louis and more recently in Kansas City. In 1879 California adopted 'a similar constitutional provision to that of Missouri, which now applies to any city of over 3,500 population; and sixteen cities in that state are operating under charters framed in this way. The same plan was adopted in the constitution of Washington in 1889 for cities of over 20,000 population, in Minnesota by constitutional amendment in 1898 ; and in Colorado in 1902 for every city of over 2,000 population. A similar procedure was adopted by the legislature of Oregon for the city of Portland in Igor. The same plan is adopted in the program of the National Municipal League for cities of over 25,000 population.

This system of "home rule" charters secures to the cities a large element of freedom from legislative interference. But the experience of St. Louis, where police, excise and election administration has been placed in the hands of state appointed officials, on the ground that these are state and not municipal interests, shows that it may 
not altogether abolish it. On the other hand, if these matters are also excluded from legislative action, there is a serious danger that municipal autonomy may be carried so far as to impair the sovereignty of the state, as has been recently urged by Governor Gage, of California. It should also be noted that this system tends to increase the confusion and complexity of the law on municipal government. In practice, too, there has sometimes been a long delay in securing the adoption of a charter under this process. The first charter submitted for Denver was rejected, and a second was framed and adopted with too little consideration. In Minneapolis, three proposed charters have failed of ratification; and the old discredited system continues in operation.

These considerations, and the frequent misrule and corruption in municipal government, make clear that the complete independence of the city from the state is not a satisfactory remedy for legislative interference. And while restrictions on special legislation and local charter conventions for the larger cities are steps in the right direction, the limitation on legislative control which they involve must be supplemented by the fuller development of other methods of control, which will be free from the evils that have accompanied the excessive dependence on the legislature. What these methods should be may be suggested by an examination of other forms of control already in existence.

\section{Judicial Control.}

To a considerable extent municipal officials are subject to the control of the judicial authorities. Suits may be brought against municipal corporations to enforce contract rights, and to some extent for damages due to negligence on the part of the agents of the municipality. Suits for damages may also be brought against municipal officials for acts performed without warrant of law. Municipal officials are also subject to criminal prosecution, not only for purely private acts, but also for misconduct in connection with their official duties. In addition to these judicial remedies to redress wrongful acts, the courts also exercise some preventive control over the acts of officials through the issue of writs of mandamus, injunction, certiorari, habeas corpus, quo zvarranto and the like by which they enforce statutory provisions governing the powers and duties of these officials. 
There is little or no opposition to this judicial control, and almost the only criticism made of it is that it is not always adequate to meet the situation. Criminal prosecutions depend for their success on the action of local prosecuting officers, local juries and local judges, who may have close political relations with the officials under trial; but recent events in different parts of the country speak well for the working of the local machinery of criminal justice. Other difficulties arise from the precautions of our judicial system in favor of persons accused of crime, which add to the difficulties of conviction, and often secure acquittal or a new trial on a technical appeal to a higher court. And in the exercise of control through special writs, judges are extremely careful not to interfere with the discretionary powers of administrative officials, even when these may have been clearly abused. Evidently there is need for some further development of state control. Something may perhaps be done in strengthening the judicial powers in this direction; but something of a different nature must be devised to exercise the supervision heretofore so badly attempted through the detailed legislative control, whose abandonment has been urged.

\section{Administrative Control.}

It remains to examine the supervision exercised by executive and administrative officers of the central state governments. Fifty years ago or less no such supervision existed over municipal officials, nor was there any effective administrative supervision even of local officials, such as sheriffs and prosecuting attorneys, who were clearly and directly subordinate agents of the state governments. In England from the time of the Normans to the Tudors the important local officers had been both appointed by the Crown and closely supervised in their actions by the Privy Council. But the internal conflicts of the seventeenth century resulted in breaking up the machinery of administrative control, although the principal local officials continued to be appointed by the central government. This system was brought over to the American colonies; but here it was completely decentralized by substituting local election for central appointment, while the régime of no administrative supervision was continued.

Compared with conditions in continental Europe or with those in Great Britain at the present time, or even with our own national 
administration, central administrative control of local officials in the American states is still very limited; and this is particularly so in the case of municipal officials. Nevertheless, there has been some development in this direction from the conditions during the first half of the nineteenth century; and an understanding of this development and the present situation may serve to indicate some features of our future policy. In this examination attention will be given to administrative supervision not only over municipal officials, but over all local officials established and authorized by the states.

Such supervision first appeared and has been furthest developed in connection with educational administration. Here decentralization was carried to the extreme in the petty school district; but over the local school authorities there is now in all of the states a superintendent of public instruction, a board of education, or other central authority. The powers of those state educational officials vary to some extent; but in most states they have control over the distribution of state school funds, direct the county supervision of schools, exercise control over the qualifications and training of teachers, and receive reports from all local school officers. In some states their powers are more extensive, most of all in New York, where the commissioner of education exercises supervision over elementary, secondary and higher education; while everywhere the state officials wield a large advisory influence beyond their compulsory powers.

Another field of state administrative supervision of local officials is that of matters affecting the public health. Most of the states have a state board of health, which act as bureaus of information and advice to local health officers; and in certain cases of delinquency can compel the local officers to take action.

In a similar way local charitable and correctional institutions are, in some of the larger states, brought under the inspection of state boards; which exercise an important advisory influence over both local authorities and the legislature, and in some cases may require the local officials to remedy serious defects or to introduce improvements.

Some steps have also been taken in establishing administrative supervision over local assessing officers. Many of the states now have state boards of equalization, which revise the total assessed valuation of local districts, so as to apportion the state property tax 
more equitably. In a number of states, certain property formerly assessed by local officers is now assessed by a state authority. And in a few states, notably Wisconsin and Michigan, state tax commissioners are given effective powers of supervision over local assessing officers in assessing property even for local taxation.

A fairly uniform line of development has been followed in connection with such state officials. When first established they are only authorized to collect information and make recommendations. Then this authority is made more effective by empowering them to require reports and by enlarging their powers and means of inspection. This is followed by some negative or preventive control, by the power to establish regulations, and in some cases by authority to use compulsory processes or remove delinquent local officials.

It is generally recognized that the supervision of such state authorities as have been noted has worked for the improvement of public administration in the fields under their control. Even where they have only informational and advisory functions, something has been accomplished; and more has been done where their powers and means are larger. They have had two distinct advantages over the legislatures and legislative committees. In the first place, by specialization of functions and longer service they become to some extent at least experts in the particular subject; in the second place, partisan influences have been to a large extent excluded, and the control exercised has not been abused for partisan ends.

Would not a further development of such administrative supervision in municipal matters be advisable? Does not the existence of so many associations of municipal officials, for the purpose of collecting and comparing information about their work, show that in this field as in others, while "power may be decentralized, knowledge to be most useful must be centralized." The collection and publication of municipal information can be more effectively done by an official state authority than by purely voluntary action; and the recommendations of such a central state bureau, based on adequate and accurate data, would serve to solve many of the difficulties of municipal administration.

Besides the work of information and advice, there are some branches of municipal government where further state adminstrative supervision would operate to the advantage both of the cities

7 J. S. Mill: Representative Government. 
and of the state as a whole. In the field of municipal finances the task of securing satisfactory data can only be accomplished on the basis of scientific and uniform method of keeping accounts in all of the cities. In most American cities municipal accounts and financial reports are still unintelligible to the ordinary citizen; and even where an understandable system is adopted in a particular city it is likely to be of little use in making comparisons with other cities using other systems. It is only on the basis of a uniform system that accurate and comparable information can be secured; and this can be secured only through a general law enforced by state officials. Some progress has been made in this direction in a few states. Wyoming for a number of years has had an examiner of public accounts, exercising powers over the financial accounts and reports of local officials similar to those in most states exercised over the accounts of banking and insurance companies. More recently Massachusetts and New York have enacted statutes providing for uniform financial reports from cities; while Ohio four years ago established an effective law for uniform municipal accounting in that state under the direction of the auditor of the state. Similar measures are being discussed in other states; and should be encouraged.

Another field where there is special need for state administrative supervision is that of the police. The courts have repeatedly recognized that in the control over the police, municipal officials are acting not as local authorities, but as agents of the state. And this view has often been made the excuse for vesting the police administration of some cities completely in state appointed authorities. This special treatment of particular cities cannot be defended on any general principle; but the judicial view of the state's authority and the interests of the state as a whole in an effective and honest police administration do warrant a general system of supervision in this field. This is not introducing any novel idea into our system of government, nor does it require any elaborate system of new officials to put it into effect. All that is necessary is to energise one of the oldest factors in our system of local government. Make it the specific duty of the county sheriffs, the responsible peace officers, to inspect the local police within their jurisdiction, and to report periodically to the governor of the state; and give to the governors in all states. a power, now partially given in some, ${ }^{8}$ to remove delinquent sheriffs or other local police officers.

- New York, Michigan, and Wisconsin. 
To summarize: The demand for municipal home rule should be made more specific and more definite. It must be made clear that what is wanted is, not a revolution involving the complete separation of the cities from the state, but a larger freedom in matters of local concern from the restrictions of detailed municipal legislation, while retaining the control of the judiciary and asking for the assistance and supervision of state officers in securing the highest and the best municipal administration in the world. 